\title{
Some Recent Articles
}

This list is not exhaustive but may be found convenient as a record of papers on subjects which are within the scope of ANTIQUITY. Books are occasionally included.

Some recent contributions to the Pleistocene succession in England, by K. S. Sandford. Geological Magazine, Jan. 1932, LxIx, I-18.

A brief critical summary of recent work, with attempted correlations between the Upper Thames, the Lower Thames, and East Anglia ; together with comments on the need of coordination of research concerned with these problems. No student of human origins can afford to miss this paper. We have in England a wealth of evidence bearing closely on man's antiquity, but it needs disentangling, and here we are given a general view of the present state of the process.

Climate, vegetation and man in the Huddersfield district, by T. W. Woodhead. Tolson Memorial Museum Publications, Handbook viII, 193I. Paper Is; limp cloth is $3 d$.

One of the completest regional studies of its kind in existence, fully illustrated by photographs of models (relief-maps); and concluding with a short chronological table from I 100 B.C. to A.D. 1000.

Post-glacial succession of forests in Europe, by T. W. Woodhead. Science Progress, October 193r, no. 102, 250-6r.

Another attempt at correlation, with a table particularly detailed in regard to vegetation.

Zur Megalithkultur Nordwest deutschlands, by Dr Ernst Sprockhoff (Römisch-Germanisch Zentral-museum, Mainz). Nachtrichten aus Niedersachsens Urgeschichte, no. 4, 1930. (August Lax, Verlags-handlung, Hildesheim). pp. 56, 23 illus.

A very useful account with many plans and three distribution sketch-maps.

Notes de préhistoire palestinienne, by R. Neuville (Jerusalem). Fourn. of the Palestine Oriental Society (Jerusalem), 1930, x, 64-75; 193-221.

Valuable notes on the classification and relative age of flint implements in Palestine -a subject which has been neglected by most of the excavators in that country. Full cognizance is taken of Miss Garrod's work. No plans or sections, however. (A criticism of the author's dating is made in the article by Dr Albright quoted in the next notice). 


\section{NOTES AND NEWS}

Recent progress in the late prehistory of Palestine, by W. F. Albright. Bull. Amer. Sch. of Oriental Research [BASOR], April I93I, no. 42, $\mathrm{I}^{-1} 5$.

The following paragraph is worth quoting in full:- ' We have now, as a result of less than three years of work on the part of a small group of scholars, a nearly complete classification of the more important successive cultures of Palestine at the end of the Stone Age. First there comes Natufian, parallel (roughly speaking) with the Tardenoisian of Europe and the latest Capsian of Egypt. Agriculture and presumably the domestication of animals begin, but pottery is unknown. Next we have the age of the first potters, the age when copper began to be used, the period of the Campignian of Europe and Faiyumian and Badarian, etc., of Egypt. Mesolithic now becomes Neolithic, not later than 4000 B.C., at the lowest computation. Nothing so far found in Palestine appears to belong in this age, which is thus a lacuna to be filled by the Palestinian archaeologist. Then comes the characteristic Chalcolithic of Palestine, the Ghassulian, which has been found in the caves of Galilee and Carmel as well as in the lower Jordan valley. Finally after 3000 B.C. we have the Early Bronze, with its Tahunian flint industry'.

The Excavations at Nuzi : preliminary report of the fourth campaign, by Prof. Robert H. Pfeiffer. BASOR, April 1931, no. 42, I-7. (Air-photograph, giving plan of excavated ruins).

On the map found at Nuzi, by W. F. Albright. BASOR, no. 42, 7-10, illus.

We hope to revert later to this very interesting clay-tablet of the 3 rd-millennium.

Letter of February 28 [1931] from Dr Speiser to the President of Dropsie College and the Director of the American School at Baghdad (Second campaign at Tepe Gawra). BASOR, April I931, no. 42, 10-12.

Describes work at this very important early tell, near Mosul. 'The peculiar fascination of Tepe Gawra is due to the fact that, of its twenty-odd strata, only four are later than the third millennium; more than ten are of the aeneolithic or prehistoric period, which belongs primarily to the fourth millennium. These numerous prehistoric levels make the mound the oldest in Iraq, a fact that can scarcely be overstated'. A critical study of the flint (and obsidian) implements, especially those from the lowest levels, seems greatly needed; no doubt such will be published in the full report. A 'potful of charred wheat' was found in a layer assigned to the fourth millennium ("Gawra I').

Excavations in the Wady el Mughara, 1931, by Dorothy Garrod. Palestine Exploration Fund, Quarterly Statement, January 1932, 46-5I.

Records the progress of excavations during $193 \mathrm{I}$ in the Wady el Mughara by Miss Garrod and her colleagues. Deposits of Mousterian and Natufian (mesolithic) age were found, together with 17 Natufian burials and the skeleton of a Mousterian child ( $2 \frac{1}{2}$ years old) of 'definite Neanderthal type' (Keith). The lower Natufian contained sickle-blade hafts. 


\section{ANTIQUITY}

Opportunism and the factors of invention, by H. S. Harrison. The American Anthropologist, Jan.-March 1930, xxxII, no. I, I06-25.

An important paper, by the Director of the Horniman Museum, on the fascinating subject of tools, treated (we think we may say) from an 'organic evolutionary ' point of view. It is not easy reading, but it must be studied by sociologists as well as by anthropologists, as it deals with fundamental matters.

Die Alamannen in Württemberg, by Walther Veeck. I93I. [Germanische Denkmäler der Volker-wanderung-zeit. Issued by the German Archaeological Institute, Frankfurt-on-Main]. Walter de Gruyter, Berlin W. IO. Paper, RM 65; bound, RM 75.

An aerial expedition to Central America, by Percy C. Madeira, Jr. Museum Fournal [Univ. of Pennsylvania, Philadelphia], June I93 I, XxII, 95-147.

The Chambered Cairn of Bryn Celli Ddu, by W. J. Hemp. Arch. Camb., Dec. 1931, Lxxxvi, 216-62.

In part a summary of and in part supplementary to the article in Archaeologia, LXxx, $179-214$, by the same author.

The Administration of Archaeology in Wales in 193I. Presidential Address by R. E. M. Wheeler. Arch. Camb., Dec. I93 I, LXxxvI, 340-52.

Roman Britain in 1930, by R. G. Collingwood and M. V. Taylor. Fournal of Roman Studies, I93I, XXI, 215-50.

The usual, and indispensable, record of excavations, inscriptions and other discoveries.

Notes on some Romano-British pigs of lead, by G. Clement Whittick. Fournal of Roman Studies, I93 I, XxI, 256-64.

Saxon Lydd, by Gordon Ward. Archaeologia Cantiana, 193r, XIIII, 29-37.

An interesting topographical study - Saxon bounds, field-work.

Notes on some West Kent roads in early maps and road-books, by E. G. Box. Arch. Cantiana, 193 I, XLIII, 85-98.

The Sturge Collection: an illustrated selection of flints from Britain bequeathed in I919 by William Allen Sturge. By Reginald Smith. London: British Museum, I93I, 25 s. 


\section{NOTES AND NEWS}

Notes on (I) certain prehistoric relics from Orkney, and (2) Skara Brae : its culture and its period, by J. Graham Callander. Proc. Soc. Ant. Scotland, I930-31, LXV, 78-II4.

The early Bronze Age flint dagger in England and Wales, by W. F. Grimes. Proc. Preh. Soc. East Anglia, 1931, vi, 340-55.

Notes on the Beaker pottery of the Ipswich Museum, by J. G. D. Clark. Ib. id. 356-6r.

The conclusions reached by the writer of this and the preceding paper are in agreement, though reached quite independently.

Archaeology of the Arkansas River Valley. By Warren King Moorehead. (With supplementary papers). pp. 205. Illustrations and sketch maps. Yale University Press : London, Humphrey Milford. Price not stated.

The illustrations depict a quantity of beautiful pottery finds in the excavations, and also figure in assiduous detail the stone implements, both chipped and polished, which were here as characteristically commingled as in many another American area. . . . Mr J. B. Thoburn writes on the prehistoric cultures of Oklahoma and makes interesting, if not always pertinent, observations on the lives and activities of the Caddoan peoples, on the possible migrations and counter-migrations which originated the so-called Canadian Culture ... Mr F. V. Studer devotes several pages to an account of his observations in the Texas Panhandle ruins, and reproduces pictures from the wall of a rock-shelter near Folsom, New Mexico, which might well have been executed in late Palaeolithic France or Spain.

J. LesLie Mitchell.

Archaeological Atlas of Michigan. By Walter B. Hinsdale. The Librarian, General Library, University of Michigan. pp. $3^{8}$ and 20 maps. 6 dollars.

A beautiful and almost faultless production. The preliminary pages give a brief sketch of the Michigan cultures, and a brief description of the different types of sites figured in the maps. The maps have been executed with a commendable elimination of unnecessary detail, and are as full as any archaeologist could wish.

J.L.M.

\section{British Columbian Ancestors of the Eskimo ? By Professor Charles} Hill-Tout. Illustrated London News, I6 January 1932.

An account of excavation in British Columbian kitchen-middens. A trephined skull, some wampum necklaces, a figurine and various stone ceremonial bowls are illustrated and described. The facts seem hardly to warrant either the headline or the hypothesis, and the 2500 years assigned to the deposits might well be cut in 


\section{ANTIQUITY}

half. The dolichocephalic pre-Salish autochthones appear to have absorbed considerable elements from an intrusive culture-or were themselves intrusive Californians, rather than ancestors of a people so remote in space and time as the Eskimo. J.L.M.

Fire Worship in Britain. By T. F. G. Dexter. New Knowledge Series (no. 4). Watts \& Co., I93I. pp. 47. Is.

It is unfortunate that Dr Dexter's very readable little work should appear under such unpropitious auspices. The verbiage of the prefatory 'Synopsis of Series' savours less of 'new knowledge ' than of certain theorizings, unacceptable to most working anthropologists, and decidedly stale. A certain flavour of 'Easterners' (together with irrelevant illustrations) is, moreover, detectable in the text. The attitude of the early Church to Pagan festivals and deities, however, is well drawn.

It was indeed 'the policy of conciliation and incorporation pursued by the early Church ' that conserved the material of Dr Dexter's study. Among the illustrations are several amusing reproductions from old prints of May Day, Midsummer and Twelfth Night festivities. J.G.D.C.

Archivo de prehistoria levantina (Annuario del servicio de investigacion prehistorica de la excma. Diputacion provincial de Valencia). Vol. I, 1928. pp. 262, with 54 plates and numerous illustrations in the text. Price not stated.

This first volume is a handsome production that does credit to the "Servicio de investigacion prehistorica ' of Valencia, and is in every way worthy of the excellent series of papers it contains ; indeed, if this new journal appears with reasonable punctuality and maintains its present high standard in the matter of printing and illustrations, then the 'machinery' of Spanish archaeology will be very considerably improved, and we shall all be correspondingly grateful to the enterprise of the Director, Sr. Ballester, and his colleagues. In this volume the most important paper is the description of the Iberian town 'La Bastida', which is illustrated by a plan and no less than 20 plates, and next to it we may rank a study by Professor BoschGimpera of the affinities between Greek and Iberian art. There is also an extremely interesting article by Sr. Primitivo Gomez that gives us a remarkable survey of Iberian prehistory, and posits an unidentified and native 'Culture of the Plains' as intermediary between the upland Megalithic Culture and the Iberian Culture proper, thus filling a gap that is otherwise unaccountable. Some novel figures showing how dolmens were built add to the value of the paper, which is entitled 'Un "Hiatus" prehistorico'. Other articles deal with earlier periods; the 'aeneolithic' is well represented both in antiquities and skeletal material (note especially the sepulchral site of Cami Real), and there is also an account by Abbé Breuil of a Le Moustier industry (roughish quartzite implements) found by him near Mineteda. Notes, reviews of books, and a really good index complete the volume. T. D. KENDRICK. 